\title{
Front Matter: Volume 8209
}

, "Front Matter: Volume 8209," Proc. SPIE 8209, Ophthalmic Technologies XXII, 820901 (14 March 2012); doi: 10.1117/12.931556

SPIE. Event: SPIE BiOS, 2012, San Francisco, California, United States 


\section{PROGRESS IN BIOMEDICAL OPTICS AND IMAGING}

Vol. 13, No. 3

\section{Ophthalmic Technologies XXII}

Fabrice Manns

Per G. Söderberg

Arthur Ho

Editors

21-22 January 2012

San Francisco, California, United States

Sponsored and Published by

SPIE

Volume 8209

Proceedings of SPIE, 1605-7422, v. 8209

SPIE is an international society advancing an interdisciplinary approach to the science and application of light. 
The papers included in this volume were part of the technical conference cited on the cover and title page. Papers were selected and subject to review by the editors and conference program committee. Some conference presentations may not be available for publication. The papers published in these proceedings reflect the work and thoughts of the authors and are published herein as submitted. The publisher is not responsible for the validity of the information or for any outcomes resulting from reliance thereon.

Please use the following format to cite material from this book:

Author(s), "Title of Paper," in Ophthalmic Technologies XXII, edited by Fabrice Manns, Per G. Söderberg, Arthur Ho, Proceedings of SPIE Vol. 8209 (SPIE, Bellingham, WA, 2012) Article CID Number.

ISSN 1605-7422

ISBN 9780819488527

Published by

SPIE

P.O. Box 10, Bellingham, Washington 98227-0010 USA

Telephone +1 3606763290 (Pacific Time) · Fax +1 3606471445

SPIE.org

Copyright (C) 2012, Society of Photo-Optical Instrumentation Engineers.

Copying of material in this book for internal or personal use, or for the internal or personal use of specific clients, beyond the fair use provisions granted by the U.S. Copyright Law is authorized by SPIE subject to payment of copying fees. The Transactional Reporting Service base fee for this volume is $\$ 18.00$ per article (or portion thereof), which should be paid directly to the Copyright Clearance Center (CCC), 222 Rosewood Drive, Danvers, MA 01923. Payment may also be made electronically through CCC Online at copyright.com. Other copying for republication, resale, advertising or promotion, or any form of systematic or multiple reproduction of any material in this book is prohibited except with permission in writing from the publisher. The CCC fee code is 1605 $7422 / 12 / \$ 18.00$.

Printed in the United States of America.

Publication of record for individual papers is online in the SPIE Digital Library.

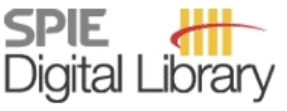

SPIEDigitallibrary.org

Paper Numbering: Proceedings of SPIE follow an e-First publication model, with papers published first online and then in print and on CD-ROM. Papers are published as they are submitted and meet publication criteria. A unique, consistent, permanent citation identifier (CID) number is assigned to each article at the time of the first publication. Utilization of CIDs allows articles to be fully citable as soon as they are published online, and connects the same identifier to all online, print, and electronic versions of the publication. SPIE uses a six-digit CID article numbering system in which:

- The first four digits correspond to the SPIE volume number.

- The last two digits indicate publication order within the volume using a Base 36 numbering system employing both numerals and letters. These two-number sets start with 00, 01, 02, 03, 04, $05,06,07,08,09,0 A, 0 B \ldots 0 Z$, followed by 10-1Z, 20-2Z, etc.

The CID number appears on each page of the manuscript. The complete citation is used on the first page, and an abbreviated version on subsequent pages. Numbers in the index correspond to the last two digits of the six-digit CID number. 


\section{Contents}

vii Conference Committee

ix Introduction

OPHTHALMIC IMAGING: MODELS

820907 In vivo quantification of microglia dynamics with a scanning laser ophthalmoscope in a mouse model of focal laser injury (Pascal Rol Award) [8209-06]

C. Alt, C. P. Lin, Wellman Ctr. for Photomedicine, Massachusetts General Hospital, Harvard Medical School (United States)

\section{OCULAR BIOMETRY}

820908 Optical remote continuous sensing of intraocular pressure variations [8209-07]

Y. Beiderman, Bar-llan Univ. (Israel); A. Skaat, M. Belkin, Tel Aviv Univ. (Israel); R.-P. Tornow, Augenklini (Germany); V. Mico, J. Garcia, Univ. de València (Spain); Z. Zalevsky, Bar-llan Univ. (Israel) and Friedrich-Alexander Univ. Erlangen-Nürnberg (Germany)

820909 Image diversity, shape modification with accommodation, dynamical change with accommodation, and age dependence of the ciliary body imaged by optical coherence tomography [8209-08]

K. Shimizu, N. Satou, A. Igarashi, M. Nakanishi, Kitasato Univ. (Japan); A. Goto, Canon Inc. (Japan); D. Choi, R. Yoshimura, H. Hiro-Oka, H. Furukawa, Kitasato Univ. (Japan);

K. Ohbayashi, Kitasato Univ. School of Medicine (Japan)

8209 OC Validation of a quasi real-time global aberrometer: the EyeMapper [8209-11]

C. Fedtke, K. Ehrmann, Brien Holden Vision Institute (Australia) and Univ. of New South Whales (Australia); D. Falk, Brien Holden Vision Institute (Australia); B. Holden, Brien Holden Vision Institute (Australia) and Univ. of New South Whales (Australia)

\section{OPHTHALMIC IMAGING: VASCULATURE AND BLOOD FLOW}

8209 OM Choroidal imaging by one-micrometer dual-beam Doppler optical coherence angiography with adjustable velocity range [8209-21]

F. Jaillon, S. Makita, Y. Yasuno, Univ. of Tsukuba (Japan) and Computational Optics and Ophthalmology Group (Japan)

820900 Differential intensity contrast swept source optical coherence tomography for human retinal vasculature visualization [8209-23]

R. Motaghiannezam, S. Fraser, Beckman Institute, California Institute of Technology (United States) 
8209 OR Swept source OCT with air puff chamber for corneal dynamics measurements [8209-26] K. Karnowski, Nicolaus Copernicus Univ. (Poland); D. Alonso-Caneiro, Nicolaus Copernicus Univ. (Poland) and Queensland Univ. of Technology (Australia); B. Kałużny, A. Kowalczyk, M. Wojtkowski, Nicolaus Copernicus Univ. (Poland)

8209 OS Estimation of surface wave propagation in mouse cornea [8209-27]

R. K. Manapuram, F. M. Menodiado, P. Truong, Univ. of Houston (United States); S. Aglyamov, S. Emelianov, Univ. of Texas at Austin (United States); M. Twa, Univ. of Houston (United States); K. V. Larin, Univ. of Houston (United States) and Saratov State Univ. (Russian Federation)

8209 OT Spatially resolved Brillouin spectroscopy for in vivo determination of the biomechanical properties of the crystalline lenses [8209-28]

O. Stachs, S. Reiß, R. Guthoff, H. Stolz, Univ. Rostock (Germany)

8209 OU Quantitative RNFL attenuation coefficient measurements by RPE-normalized OCT data [8209-29]

K. A. Vermeer, J. van der Schoot, H. G. Lemij, Rotterdam Eye Hospital (Netherlands) and Rotterdam Ophthalmic Institute (Netherlands); J. F. de Boer, Rotterdam Eye Hospital (Netherlands) and Rotterdam Ophthalmic Institute (Netherlands) and VU Univ., Amsterdam (Netherlands)

\section{OPHTHALMIC SURGERY: LASERS AND IMAGING}

$82090 Z$ A miniature forward-imaging optical coherence tomography probe [8209-34]

K. M. Joos, J.-H. Shen, Vanderbilt Univ. (United States)

\section{OPHTHALMIC ADAPTIVE OPTICS}

8209 1G In-vivo imaging of inner retinal cellular morphology with adaptive optics - optical coherence tomography: challenges and possible solutions [8209-51]

R. J. Zawadzki, UC Davis Medical Ctr. (United States); S. M. Jones, Lawrence Livermore National Lab. (United States); D. Y. Kim, UC Davis Medical Ctr. (United States); L. Poyneer, Lawrence Livermore National Lab. (United States); A. G. Capps, UC Davis Medical Ctr. (United States) and Univ. of California, Davis (United States); B. Hamann, Univ. of California, Davis (United States); S. S. Olivier, Lawrence Livermore National Lab. (United States); J. S. Werner, UC Davis Medical Ctr. (United States)

$820911 \quad$ Adaptive optics optical coherence tomography for measuring phase and reflectance dynamics of photoreceptors [8209-53]

O. P. Kocaoglu, R. S. Jonnal, S. Lee, Q. Wang, Z. Liu, D. T. Miller, Indiana Univ. (United States)

\section{POSTER SESSION}

$82091 \mathrm{~J} \quad$ Effect of dehydration in the UV transmittance of "in vitro" corneas [8209-54]

V. A. C. Lincoln, L. Ventura, S. J. Faria e Sousa, M. M. Mello, Univ. de São Paulo (Brazil)

$82091 \mathrm{~K}$ A prototype for measurements in visible light transmittance of sunglasses [8209-55] M. M. Mello, V. A. C. Lincoln, L. Ventura, Univ. de São Paulo (Brazil) 
8209 1L Spectroscopic measurements during the corneal collagen cross-linking procedure for in vitro human corneas [8209-56]

L. Ventura, V. A. C. Lincoln, M. M. Mello, S. J. Faria e Sousa, Univ. de São Paulo (Brazil)

$82091 \mathrm{M}$ Does tropicamide affect choroidal blood flow in humans? a laser Doppler flowmetry study [8209-57]

N. Palanisamy, Univ. degli Studi di Modena e Reggio Emilia (Italy); C. E. Riva, Univ. de Lausanne (Switzerland); L. Rovati, Univ. degli Studi di Modena e Reggio Emilia (Italy); M. Cellini, C. Gizzi, E. Strobbe, E. C. Campos, Univ. degli Studi di Bologna (Italy)

8209 iN Innovative ophthalmic instrument to detect nano- and micro-aggregates in blood circulation [8209-58]

L. Rovati, S. Cattini, R. Salvatori, Univ. degli Studi di Modena e Reggio Emilia (Italy); A. Gatti, Istituto di Scienza e Tecnologia dei Materiali Ceramici (Italy)

820910 "All-laser" endothelial corneal transplant in human patients [8209-59]

F. Rossi, Istituto di Fisica Applicata Nello Carrara (Italy); L. Menabuoni, A. Malandrini, A. Canovetti, I. Lenzetti, U.O. Oculistica - Ospedale Misericordia e Dolce (Italy); R. Pini, Istituto di Fisica Applicata Nello Carrara (Italy)

8209 is Evaluation of water film thickness on contact lens by improved reflectometry technique [8209-63]

H. Lu, M. R. Wang, Univ. of Miami (United States); J. Wang, Bascom Palmer Eye Institute, Univ. of Miami (United States)

8209 1T Portable retinal imaging for eye disease screening using a consumer-grade digital camera [8209-65]

S. Barriga, VisionQuest Biomedical, LLC (United States) and Univ. of New Mexico (United States); A. Larichev, G. Zamora, Lomonosov Moscow State Univ. (Russian Federation); P. Soliz, VisionQuest Biomedical, LLC (United States) and Univ. of lowa (United States)

$82091 \mathrm{U} \quad$ Toward optical coherence topography [8209-66]

S. Sayegh, Y. Jiang, The Eye Ctr. (United States)

$82091 \mathrm{~V}$ Toward the development of a low-cost laser Doppler module for ophthalmic microscopes [8209-67]

S. Cattini, L. Rovati, Univ. degli Studi di Modena e Reggio Emilia (Italy)

8209 1W Corneal tissue ablation using 6.1 $\mu \mathrm{m}$ quantum cascade laser [8209-68]

Y. Huang, J. U. Kang, The Johns Hopkins Univ. (United States)

8209 1X Spatially highly resolved aberrometer: first exprimental characterizations and assessments [8209-69]

B. Emica, S. Meimon, J.-M. Conan, T. Fusco, ONERA (France); G. Chenegros, Institut de la Vision (France) and Observatoire de Paris, Lab. d'études Spatiales et d'Instrumentation en Astrophysique (France); M. Paques, Institut National de la Santé et de la Recherche Médicale (France)

Author Index 
Downloaded From: https://www.spiedigitallibrary.org/conference-proceedings-of-spie on 25 Apr 2023

Terms of Use: https://www.spiedigitallibrary.org/terms-of-use 


\title{
Conference Committee
}

\author{
Symposium Chairs
}

James G. Fujimoto, Massachusetts Institute of Technology

(United States)

R. Rox Anderson, Wellman Center for Photomedicine, Massachusetts

General Hospital, Harvard School of Medicine (United States)

Program Track Chair

Brian Jet-Fei Wong, Beckman Laser Institute and Medical Clinic

(United States)

Conference Chairs

Fabrice Manns, University of Miami (United States)

Per G. Söderberg, Uppsala Universitet (Sweden)

Arthur Ho, Brien Holden Vision Institute (Australia)

Program Committee

Rafat R. Ansari, NASA Glenn Research Center (United States)

Michael Belkin, Tel Aviv University (Israel)

Ralf Brinkmann, Universität zu Lübeck (Germany)

Wolfgang Drexler, Medizinische Universität Wien (Austria)

Daniel X. Hammer, Physical Sciences Inc. (United States)

Karen M. Joos, Vanderbilt University (United States)

Katsuhiko Kobayashi, Topcon Corporation (Japan)

Kirill V. Larin, University of Houston (United States)

Ezra Maguen, American Eye Institute (United States)

Donald T. Miller, Indiana University (United States)

Daniel V. Palanker, Stanford University School of Medicine (United States)

Jean-Marie Parel, Bascom Palmer Eye Institute (United States)

Roberto Pini, Istituto di Fisica Applicata Nello Carrara (Italy)

Luigi L. Rovati, Università degli Studi di Modena e Reggio Emilia (Italy)

Georg Schuele, OptiMedica Corporation (United States)

Jerry Sebag, The University of Southern California (United States)

Peter Soliz, VisionQuest Biomedical, LLC (United States)

William B. Telfair, IRIDEX Corporation (United States)

Valery V. Tuchin, N.G. Chernyshevsky Saratov State University (Russian Federation) 
Session Chairs

1 Ophthalmic Imaging: Models

Daniel X. Hammer, Physical Sciences Inc. (United States)

Karen M. Joos, Vanderbilt University (United States)

2 Ocular Biometry

Ezra Maguen, American Eye Institute (United States)

Luigi L. Rovati, Università degli Studi di Modena e Reggio Emilia (Italy)

3 Keynote Session

Per G. Söderberg, Uppsala Universitet (Sweden)

4 Ophthalmic Imaging: Motion, Registration, Segmentation, Correction

Wolfgang Drexler, Medizinische Universität Wien (Austria)

Georg Schuele, OptiMedica Corporation (United States)

5 Ophthalmic Imaging: Vasculature and Blood Flow

Luigi L. Rovati, Università degli Studi di Modena e Reggio Emilia (Italy)

Kirill V. Larin, University of Houston (United States)

6 Ophthalmic Tissues: Optics, Mechanics, and Light Interactions

Arthur Ho, Brien Holden Vision Institute (Australia)

Ezra Maguen, American Eye Institute (United States)

$7 \quad$ Ophthalmic Surgery: Lasers and Imaging

William B. Telfair, IRIDEX Corporation (United States)

Georg Schuele, OptiMedica Corporation (United States)

8 Ophthalmic OCT: Technology

Wolfgang Drexler, Medizinische Universität Wien (Austria)

Daniel V. Palanker, Stanford University School of Medicine (United States)

9 Ophthalmic Imaging: Polarization

Per G. Söderberg, Uppsala Universitet (Sweden)

10 Ophthalmic Adaptive Optics

Daniel X. Hammer, Physical Sciences Inc. (United States)

Peter Soliz, VisionQuest Biomedical, LLC (United States) 


\section{Introduction}

The papers contained in this volume were presented at the twenty-second conference on Ophthalmic Technologies, held from January 21 to 22, 2012, at the Moscone Center in San Francisco, California as a part of the SPIE Photonics West BiOS Meeting.

A total of 52 papers and 16 posters were presented by scientists, clinicians, and engineers from academia, private clinics, and industry representing many different countries covering 5 different continents. Topics included advances in adaptive optics for retinal imaging, new technologies and applications of optical coherence tomography, and a novel laser for corneal surgery.

The twelfth Pascal Rol Award was presented to Dr. Clemens Alt and his colleagues from Harvard University, CA for their excellent paper on "In vivo quantification of microglia dynamics with a scanning laser ophthalmoscope in a mouse model of focal laser injury" (8209-06). Established in memory of Dr. Pascal O. Rol, former chair and co-founder of the Ophthalmic Technologies conference, the award is in recognition of the best manuscript and presentation. The outstanding finalists were Drs. Choi (8209-03), Kocaoglu (8209-53), and Potsaid (8209-38).

The conference hosted its seventh presentation on the topic of unmet technological needs in a clinical area. Prof. Robin Ali, from the Institute of Ophthalmology at the University College in London, UK, gave an outstanding overview of the challenges and technological needs in the field of molecular therapy of retinal diseases.

We are very grateful to the Brien Holden Vision Institute in Sydney, Australia, for sponsoring the 2012 Pascal Rol award and keynote lecture through the Pascal Rol Foundation.

We thank the Program Committee members, session chairs, speakers and participants, as well as the SPIE staff for their support and dedication in making this conference a success.

We extend an invitation for the Ophthalmic Technologies XXIII conference, which is scheduled for Saturday February 2 and Sunday February 3, 2013 in San Francisco, CA.

Fabrice Manns

Per Söderberg

Arthur Ho 
Downloaded From: https://www.spiedigitallibrary.org/conference-proceedings-of-spie on 25 Apr 2023

Terms of Use: https://www.spiedigitallibrary.org/terms-of-use 